Research Artide

JOURNAL OF THE CAMEROON ACADEMY OF SCIENCES Vol. 14 No. 3 (JANUARY 2019)

\title{
Spatio-temporal variation of the physico-chemical properties of rainwater in Benin City, Nigeria
}

\author{
Godwin 0. Atedhor ${ }^{1 *}$, Amidu 0. Ayeni ${ }^{2}$ and Judith A. Aiyeki ${ }^{1}$ \\ ${ }^{1}$ D epartment of G eography and Regional Planning, University of Benin, Benin City, Nigeria \\ ${ }^{2}$ D epartment of G eography, University of Lagos, Lagos, Nigeria \\ *Corresponding author: godwin.atedhor@uniben.edu, +2348136446117
}

\begin{abstract}
Urbanized landscapes are known to have relatively high atmospheric pollutants due to high concentration of anthropogenic activities. This paper therefore examines the spatial and temporal variations of the physico-chemical properties of rainwater at the core, intermediate and urban fringe of Benin City. Rainwater samples were collected at 2 locations each at the core (Ring Road and Forestry), intermediate (Airport Road and Upper Mission) and urban fringe (Ikpoba Hill and O gba) in the months of March and July, 2016. The physico-chemical properties of the rainwater differed significantly at the core, intermediate and urban fringe between the months of March and July with t-statistics of 3.029, 3.737 and $2.764(p<0.05)$ respectively. The difference in rainwater properties among the core, intermediate and urban fringe zones were insignificant in the months of March and July. With the exceptions of colour, turbidity, P and Fe in the month of March and P and Fe in the month of July, rainwater properties from the three locations, where WHO guidelines for drinking water is applicable, were within permissible limits. Water quality was excellent at the core, intermediate and urban in the month of July while it was excellent at the intermediate and urban fringe and good at the core in the month of March. Findings suggest that besides the role of rainfall amount in atmospheric cleansing, other factors such as wind profile and direction and atmospheric stagnation also play critical influence on rainwater quality.
\end{abstract}

Keywords: Rainwater, water quality index, physico-chemical properties, Benin City, Nigeria

\section{Resumé}

On sait que les paysages urbanisés présentent des polluants atmosphériques relativement élevés en raison de la concentration élevée d'activités anthropiques. Cet article examine donc les variations spatio-temporelles des propriétés physico-chimiques de l'eau de pluie à la périphérie centrale, intermédiaire et urbaine de Benin City. Des échantillons d'eau de pluie ont été collectés à deux endroits situés respectivement aux quartiers centraux (Route Périphérique et Forêt), intermédiaires (Route A éroportuaire et Upper Mission) et urbains (Ikpoba Hill et O gba) en mars et juillet 2016. Les propriétés physico-chimiques des eaux pluviales différaient significativement aux franges centrales, intermédiaires et urbaines entre les mois de mars et juillet avec des statistiques t de 3,029, 3,737 et 2,764 ( $p<0,05)$ respectivement. La différence de propriétés des eaux de pluie entre les zones centrales, intermédiaires et urbaines était insignifiante aux mois de mars et juillet. À l'exception de la couleur, de la turbidité, du P et du Fe au mois de mars et du P et du Fe au mois de juillet, les propriétés des eaux de pluie des trois sites, où les directives de l'O MS pour l'eau potable sont applicables, étaient dans les limites permises. La qualité de l'eau était excellente au centre, intermédiaire et urbaine au mois de juillet, tandis qu'elle était excellente à la périphérie intermédiaire et urbaine et bonne au centre au mois de mars. Les résultats suggèrent qu'outre le rôle de la quantité de pluie dans le nettoyage atmosphérique, d'autres facteurs tels que le profil et la direction du vent et la stagnation atmosphérique ont également une influence déterminante sur la qualité de l'eau de pluie.

Mots-clés: Eaux de pluie, indice de qualité de l'eau, propriétés physico-chimiques, Benin City, Nigéria

\section{Received: $18 / 06 / 2018$}

Accepted: 16/ 12/ 2018

DO I: https:/ / dx.doi.org/ 10.4314/ jcas.v14i3.4

(C) The Authors. This work is licensed under the Creative Commons Attribution 4.0 International Licence. 


\section{Introduction}

The rapidity of urbanization has its attendant challenges, especially in developing countries (Balogun and Balogun, 2014). Simultaneously, growths in population and human activities in urban landscapes enhance pollutant release and particulate loading in the atmosphere (Zhong \& al., 2017). D ensely settled areas discharge substantial quantities of effluence into the atmosphere (Baklanov \& al., 2017). Thus, the transformation of rural domains into urban spaces, significantly influence the local air quality (G eorge $A a l ., 2007)$. The state of the atmosphere over an urbanized area may differ significantly due to relatively high and increasing load of atmospheric impurities.

On the bases of their properties, atmospheric impurities may be physical, chemical and biological. The physical constituents of the atmosphere essentially cover all forms of particulate matters or aerosols while it is chemically composed of gases that are constant in amount (e.g. nitrogen and oxygen) and those that are variable (e.g. $\mathrm{CO}_{2}, \mathrm{CH}_{4}, \mathrm{CO}$, water vapour). Biologically, the atmosphere harbours microbial, some of which are causal factors of human diseases. A erosols particles have been identified as critical factor in ecosystem biogeochemistry and nutrient cycling, as well as cloud development processes (Artaxo, \& al., 2002).

Urbanization dramatically increases impervious surfaces which together with other urban fabrics aggravate thermal island phenomenon (Papafotiou and Katsifarakis, 2015; Babalola and Akinsanola, 2016). Thus, urbanization-related population increase will induce environmental alteration which has bearing with atmospheric composition of cities, in addition to the canopy layer urban heat island, thermal sensation and diverse forms of air pollution (Balogun and Balogun, 2014). Urban fabrics such as buildings, contrasting neighbourhood materials, relief and infrastructure control the degree of conversion and pathways of water during its conversion from atmosphere to the ground (McGrane, 2016). Human-related emission of aerosols can influence cloud and precipitation through aerosol-cloud interactions (Zhong \& al, 2017).

The global increasing population trends in urban areas have implications on environmental quality and pressure on basic amenities. The atmosphere is dynamic both spatially and seasonally. Although water meant for domestic use is expected to be comparatively clean (Ayeni and Atedhor, 2017), the quality of rainwater which remains a major source of water in many climes due to poor access to potable water may vary over space and time in response to the dynamics of the atmosphere.

The scarcity of potable water is increasingly becoming a major challenge, especially in developing countries (Yususf and Oladipo, 2012; Inkani, 2016; Balogun \& al., 2016). Studies have shown increasing contamination of ground and surface water resources in recent years (Balogun and Adegun, 2011 and 2012; Abua \& al., 2014; Ayeni and Soneye, 2014; Oyatayo \& al., 2015). This has led to increasing interest in rainwater harvesting (Mohammed \& al., 2018). However, the seasonal variation of the quality of rainwater in a rapidly expanding urban landscape such as Benin deserves evaluation in the face of increasing urban pollution. This paper therefore examines the spatial and temporal variations of the physico-chemical properties of water in Benin City, Nigeria.

\section{Methodology \\ Study Area}

Benin City is a pre-colonial settlement and the capital of Edo State of Nigeria. The City which is situated in the humid rainforest belt of Nigeria lies within latitude $06^{\circ} 19^{\mathrm{I}} \mathrm{E}$ to $06^{\circ} 21^{\mathrm{I}} \mathrm{E}$ and longitude $5^{\circ} 34^{\mathrm{I}} \mathrm{E}$ to $5^{\circ} 44^{\mathrm{I}} \mathrm{E}$ (Figure1). The wet season covers the months of March to October (Odekunle, 2004) with annual rainfall amount 
usually up to $2000 \mathrm{~mm}$ and mean temperature approximately $27^{\circ} \mathrm{C}$. The month of March is the warmest month in the forest belt of Nigeria due to increasing cloudiness during transition from the dry season to the wet season (Atedhor and JohnAbebe, 2017) while the month of July is one of the months of peak rainfall since rainfall in the forest belt of Nigeria is bimodal with September being the second month of peak rainfall. From a total population of 762, 717 based on the 1991 census figures, the population of the city grew to
1,086,882 based on the 2006 census. Benin City has a radial network of roads which converge at the city centre. Economic activities are dominantly commercial and are largely concentrated at the city centre. These commercial activities generate huge waste that sometimes constitute nuisance due to poor refuse evacuation. The high vehicular traffic coupled with pockets of industrial activities remains sources of effluents.

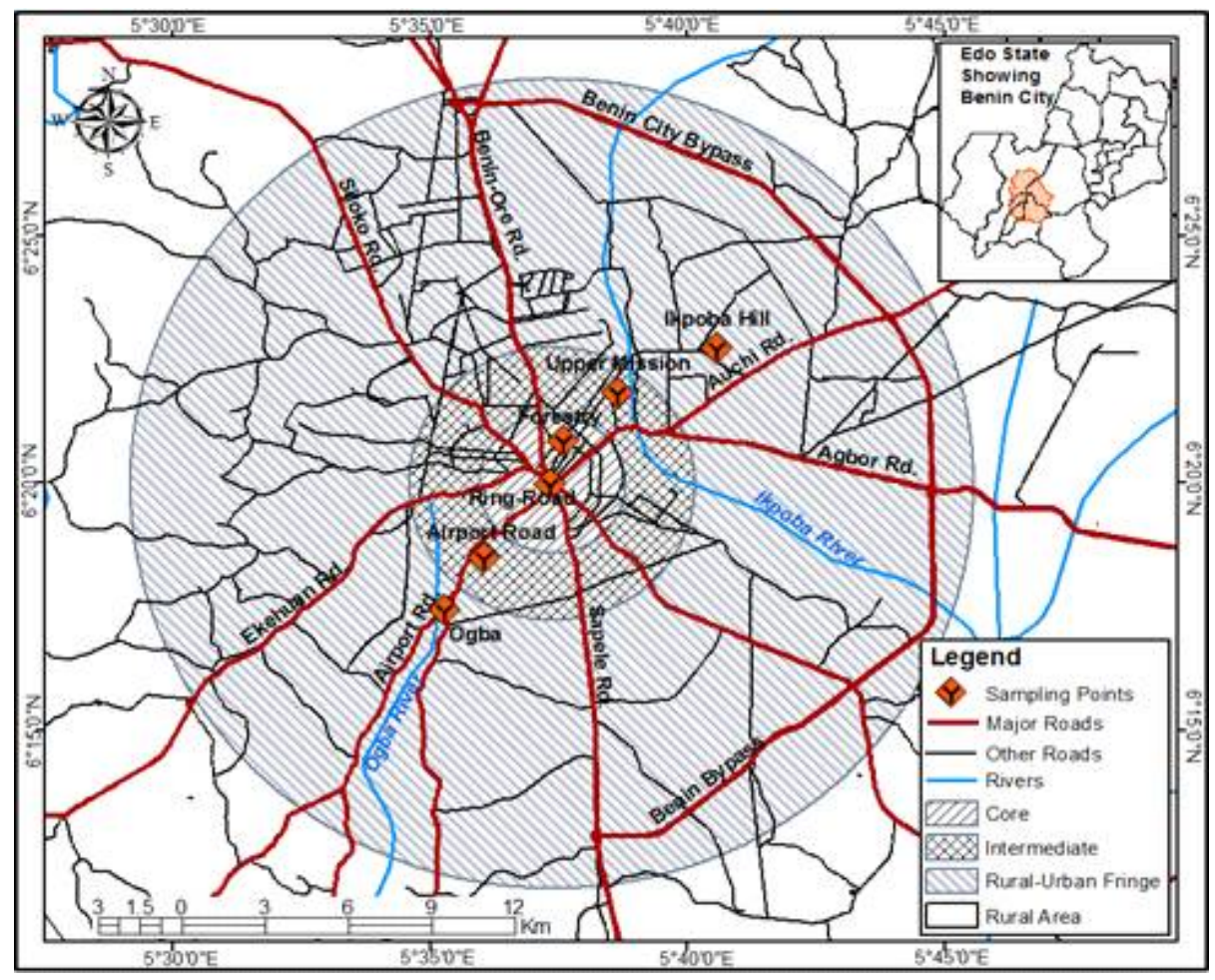

Figure 1: Benin City and Sampling Points (Inset: Edo State)

\section{Sampling Locations and Cdlection of Water}

Atmospheric chemistry varies seasonally (Idso \& al., 2002). Rainwater samples were collected in the core, intermediate and periphery of the Benin City (Figure 1) in the months of March (onset of the wet season) and July (peak of the rainy season) in 2016. The sampling locations were the core made up of Forestry $\left(\mathrm{N}_{0} 6^{\circ} 20.243^{\mathrm{I}}\right.$ and E005 $37.559^{\mathrm{I}}$ ) and Ring-Road (N06 ${ }^{\circ} 19.973^{\mathrm{I}}$ and E005 $37.325^{\mathrm{I}}$ ), intermediate comprising Upper Mission (N06 $22.437^{\mathrm{I}}$ and E005 $\left.39.544^{\mathrm{I}}\right)$ and Airport Road (N06 $19.713^{\mathrm{I}}$ and E005ㅇ․ $39.986^{\mathrm{I}}$ ) and the periphery made up of Ikpoba Hill (N06 $20.671^{\mathrm{I}}$ and $\mathrm{E} 005^{\circ} 39.986^{\mathrm{I}}$ ) and $\mathrm{Ogba}$ (N06 ${ }^{\circ} 17.656^{\mathrm{I}}$ and E $005^{\circ} 35.426^{\mathrm{I}}$ ). The physicochemical properties of the water samples were analyzed in the laboratory of the Nigerian Institute of Oil Palm Research (NIFOR).

\section{Data Analysis}

Descriptive statistics (mean, maximum, minimum and range) were used to analyze the variation of the physico-chemical characteristics of rainwater among the sampling points. The data 
of physico-chemical properties were stated in three decimal places to account for slight variations. T-test was used to assess the significance of the difference of the physicochemical properties of the rainwater between March and July. The variations of the physicochemical properties of the rainwater samples among the core, intermediate and urban fringe in the month of March and July were analyzed using analysis of variance (ANOVA).

The water quality index (WQI) was calculated to evaluate the influence of the natural and anthropogenic activities on several key parameters of water chemistry (Ramakrishnaiah A al., 2009; Ayeni and Atedhor, 2017). The processing involved three stages. The first stage involved assigning weight (wi) to each of the parameters according to their relative importance in the quality of water for drinking purposes. The assigned weights range from 1 (minimum) to 5 (maximum). The weight of 5 was assigned to nitrate and TDS, 4 to $\mathrm{pH}, \mathrm{EC}, \mathrm{SO} 4,3$ to $\mathrm{HCO}$, $\mathrm{CL}, 2$ to $\mathrm{Ca}, \mathrm{Na}$, $\mathrm{K}$ while 1 was assigned to $\mathrm{Mg}$ (Vasanthavigar \& al., 2010). The second stage involved the computation of relative weight (Wi) using the equation " $a$ ".

$$
\mathrm{W}_{\mathrm{i}}=\frac{\mathrm{w}_{\mathrm{i}}}{\sum_{\mathrm{i}=1}^{\mathrm{n}} \mathrm{w}_{\mathrm{i}}}
$$

Where $\mathrm{Wi}$ is the relative weight, wi is the weight of each parameter, and $n$ is the number of parameters. The third stage involved assigning quality rating scale (qi) for each parameter using $\bar{q}_{\mathrm{i}}=\left(\mathrm{C}_{\mathrm{i}} / \mathrm{S}_{\mathrm{i}}\right) \times$ ionuidelines of WHO (2011) as shown in equation "b"

$$
\text { (b) }
$$

Where, qi is the quality rating, $\mathrm{Ci}$ is the concentration of each chemical parameter in each water sample in $\mathrm{mg} / \mathrm{l}$, and, $\mathrm{Si}$ is the WHO (2011) guidelines for drinking water quality for each parameter. In computing the WQI, the Sli was determined first for each parameter which was then used to determine the WQI as expressed in equations "ci" and "cii".

$$
\begin{aligned}
& \mathrm{SI}_{\mathrm{i}}=\mathrm{W}_{\mathrm{i}} \cdot \mathrm{q}_{\mathrm{i}} \\
& \mathrm{WQI}=\Sigma \mathrm{SI}_{\mathrm{i}}
\end{aligned}
$$

Where SIi is the sub-index of ith parameter; qi is the rating based on concentration of ith parameter and $\mathrm{n}$ is the number of parameters. The computed WQI values were classified into five categories (Table 1) based on Sahu and Sikdar (2008).

Table 1: Water quality index classification

\begin{tabular}{cl}
\hline WQI range & Water quality \\
\hline$<50$ & Excellent \\
$50-100$ & G ood \\
$100-200$ & Poor \\
$200-300$ & Very poor \\
$>300$ & Unsuitable for drinking
\end{tabular}

\section{Results and Discussion}

The physico-chemical properties of the rainwater samples in the months of March and July are presented in Tables 2 and 3 respectively. 
Table 2: Descriptive statistics of physico-chemical properties of rainwater for the core, intermediate and urban fringe in the month March

\begin{tabular}{|c|c|c|c|c|c|c|c|c|}
\hline Param eter & $\begin{array}{l}\text { Maximum } \\
\text { permissible } \\
\text { limit }\end{array}$ & Core & Interm ediate & $\begin{array}{l}\text { Urban } \\
\text { fringe }\end{array}$ & Mean & Maximum & Minimum & Range \\
\hline $\begin{array}{l}\mathrm{pH} \\
\text { Electrical Conductivity (EC) }\end{array}$ & 8.5 & 6.835 & 6.880 & 6.955 & 6.890 & 6.955 & 6.835 & 0.120 \\
\hline$(\mu \mathrm{S} / \mathrm{cm})$ & $*$ & 95.500 & 69.600 & 72.050 & 79.050 & 95.500 & 69.600 & 25.900 \\
\hline Salinity (g/ l) & $*$ & 0.043 & 0.032 & 0.033 & 0.036 & 0.043 & 0.032 & 0.012 \\
\hline Colour (Pt.Co) & $<5$ & 8.000 & 11.800 & 6.750 & 8.850 & 11.800 & 6.750 & 5.050 \\
\hline Turbidity (NTU) & 1 & 6.950 & 10.600 & 5.850 & 7.800 & 10.600 & 5.850 & 4.750 \\
\hline Total Suspended Solid (mg/ l) & $*$ & 13.750 & 10.600 & 10.150 & 11.500 & 13.750 & 10.150 & 3.600 \\
\hline Total Dissolved Solid (mg/ l) & 500 & 47.750 & 35.150 & 36.050 & 39.650 & 47.750 & 35.150 & 12.600 \\
\hline Chemical Oxygen D emand (mg/l) & $*$ & 17.800 & 15.550 & 17.950 & 17.100 & 17.950 & 15.550 & 2.400 \\
\hline$(\mathrm{mg} / \mathrm{l})$ & $*$ & 27.450 & 24.400 & 27.450 & 26.433 & 27.450 & 24.400 & 3.050 \\
\hline Sodium (Na) (mg/ l) & $* *$ & 2.785 & 1.450 & 1.265 & 1.833 & 2.785 & 1.265 & 1.520 \\
\hline Potassium (K) (mg/ l) & $* *$ & 0.455 & 0.175 & 0.145 & 0.258 & 0.455 & 0.145 & 0.310 \\
\hline Caldum (Ca) (mg/ l) & 250 & 5.000 & 2.725 & 2.570 & 3.432 & 5.000 & 2.570 & 2.430 \\
\hline Magnesium (Mg) (mg/ l) & 150 & 1.920 & 0.645 & 0.815 & 1.127 & 1.920 & 0.645 & 1.275 \\
\hline Chloride (Cl-) mg/ l & 250 & 27.550 & 26.650 & 28.900 & 27.700 & 28.900 & 26.650 & 2.250 \\
\hline Phosphorus (P) (mg/ l) & 0.03 & 2.445 & 1.590 & 1.685 & 1.907 & 2.445 & 1.590 & 0.855 \\
\hline $\begin{array}{l}\text { Ammonium Nitrogen }\left(\mathrm{NH}_{4}-\mathrm{H}\right) \\
(\mathrm{mg} / \mathrm{l})\end{array}$ & $*$ & 0.115 & 0.085 & 0.115 & 0.105 & 0.115 & 0.085 & 0.030 \\
\hline Nitrate $\left(\mathrm{NO}_{3}\right) \mathrm{mg} / \mathrm{l}$ & 10 & 4.140 & 3.015 & 2.670 & 3.275 & 4.140 & 2.670 & 1.470 \\
\hline Sulphate $\left(\mathrm{SO}_{4}^{2-}\right)(\mathrm{mg} / \mathrm{l})$ & $*$ & 0.870 & 0.630 & 0.645 & 0.715 & 0.870 & 0.630 & 0.240 \\
\hline Iron (Fe) (mg/ l) & 0.03 & 1.275 & 0.800 & 1.005 & 1.027 & 1.275 & 0.800 & 0.475 \\
\hline Manganese (Mn) (mg/ l) & 1 & 0.048 & 0.035 & 0.029 & 0.037 & 0.048 & 0.029 & 0.019 \\
\hline Zn (Zn) (mg/ l) & 5 & 0.440 & 0.290 & 0.305 & 0.345 & 0.440 & 0.290 & 0.150 \\
\hline Copper $(\mathrm{Cu})(\mathrm{mg} / \mathrm{l})$ & 1 & 0.018 & 0.013 & 0.022 & 0.017 & 0.022 & 0.013 & 0.010 \\
\hline Chromium (Cr) (mg/ l) & 0.05 & 0.009 & 0.008 & 0.006 & 0.008 & 0.009 & 0.006 & 0.003 \\
\hline Cadmium (Cd) (mg/ l) & 0 & 0.006 & ND & 0.003 & 0.005 & 0.006 & 0.003 & 0.003 \\
\hline Lead $(\mathrm{Pb})(\mathrm{mg} / \mathrm{l})$ & 0.05 & 0.039 & 0.014 & 0.008 & 0.020 & 0.039 & 0.008 & 0.031 \\
\hline
\end{tabular}

\section{* Not covered byWHO, ** Nohelth-based guiddinevaluehas been deived byWHO, ND Not Deteted}


REVUE DE L'ACADEMIE DES SCIENCES DU CAMEROUN Vol. 14 No. 3 (Janvier 2019)

Table 3: D escriptive statistics of physico-chemical properties of rainwater for the sampling points in July

\begin{tabular}{|c|c|c|c|c|c|c|c|c|}
\hline Parameter & $\begin{array}{l}\text { Maximum } \\
\text { permissible } \\
\text { limit }\end{array}$ & Core & Intermediate & $\begin{array}{l}\text { Urban } \\
\text { fringe }\end{array}$ & Mean & Maximum & Minimum & Range \\
\hline $\mathrm{pH}$ & 8.5 & 5.760 & 5.285 & 5.720 & 5.588 & 5.760 & 5.285 & 0.475 \\
\hline Electrical Conductivity $(\mathrm{EC})(\mu \mathrm{S} / \mathrm{cm})$ & $*$ & 52.950 & 60.550 & 75.500 & 63.000 & 75.500 & 52.950 & 22.550 \\
\hline Salinity ( $g / \mathrm{l}$ ) & $*$ & 0.024 & 0.033 & 0.034 & 0.030 & 0.034 & 0.024 & 0.010 \\
\hline Colour (NTU) & $<5$ & ND & ND & ND & - & - & - & - \\
\hline Turbidity (NTU) & 1 & ND & ND & ND & - & - & - & - \\
\hline Total Suspended Solid (mg/ l) & $*$ & 2.050 & 1.550 & 2.900 & 2.167 & 2.900 & 1.550 & 1.350 \\
\hline Total Dissolved Solid (mg/ l) & 500 & 23.800 & 27.100 & 34.000 & 28.300 & 34.000 & 23.800 & 10.200 \\
\hline Chemical O xygen D emand (mg/ l) & $*$ & 3.350 & 1.700 & 1.850 & 2.300 & 3.350 & 1.700 & 1.650 \\
\hline Hydrogen Carbonate $\left(\mathrm{HCO}_{3}\right)(\mathrm{mg} / \mathrm{l})$ & * & 12.400 & 14.850 & 16.750 & 14.667 & 16.750 & 12.400 & 4.350 \\
\hline Sodium (Na) (mg/l) & $* *$ & 0.490 & 0.695 & 0.795 & 0.660 & 0.795 & 0.490 & 0.305 \\
\hline Potassium (K) (mg/ l) & $* *$ & 0.085 & 0.110 & 0.130 & 0.108 & 0.130 & 0.085 & 0.045 \\
\hline Calcium (Ca) (mg/ l) & 250 & 1.545 & 1.805 & 2.215 & 1.855 & 2.215 & 1.545 & 0.670 \\
\hline Magnesium (mg) (mg/ l) & 150 & 0.400 & 0.505 & 0.660 & 0.522 & 0.660 & 0.400 & 0.260 \\
\hline Chloride (Cl-) (mg/ l) & 250 & 19.150 & 21.900 & 23.650 & 21.567 & 23.650 & 19.150 & 4.500 \\
\hline $\begin{array}{l}\text { Phosphorus (P) } \\
\text { Ammonium Nitrogen }\left(\mathrm{NH}_{4} \cdot \mathrm{H}\right)\end{array}$ & 0.03 & 0.120 & 0.149 & 0.189 & 0.152 & 0.189 & 0.120 & 0.069 \\
\hline$(\mathrm{mg} / \mathrm{l})$ & * & ND & ND & ND & - & - & - & - \\
\hline Nitrate $\left(\mathrm{NO}_{3^{-}}^{-}\right)(\mathrm{mg} / \mathrm{l})$ & 10 & 0.206 & 0.211 & 0.265 & 0.227 & 0.265 & 0.206 & 0.060 \\
\hline Sulphate $\left(\mathrm{SO}_{4}^{2-}\right)(\mathrm{mg} / \mathrm{l})$ & $*$ & 0.130 & 0.150 & 0.175 & 0.152 & 0.175 & 0.130 & 0.045 \\
\hline Iron $(\mathrm{Fe})(\mathrm{mg} / \mathrm{l})$ & 0.03 & 0.235 & 0.245 & 0.295 & 0.258 & 0.295 & 0.235 & 0.060 \\
\hline Manganese (Mn) (mg/ l) & 1 & 0.020 & 0.026 & 0.020 & 0.022 & 0.026 & 0.020 & 0.007 \\
\hline $\mathrm{Zn}(\mathrm{Zn})(\mathrm{mg} / \mathrm{l})$ & 5 & 0.126 & 0.079 & 0.116 & 0.107 & 0.126 & 0.079 & 0.047 \\
\hline Copper (Cu) (mg/ l) & 1 & 0.006 & 0.007 & 0.007 & 0.007 & 0.007 & 0.006 & 0.002 \\
\hline Chromium (Cr) (mg/ l) & 0.05 & ND & ND & ND & - & - & - & - \\
\hline Cadmium $(\mathrm{Cd})(\mathrm{mg} / \mathrm{l})$ & 0 & ND & ND & ND & - & - & - & - \\
\hline Lead $(\mathrm{Pb})(\mathrm{mg} / \mathrm{l})$ & 0.05 & ND & ND & ND & - & - & - & - \\
\hline
\end{tabular}

* Nct coveed byWHO, ** Nohelth-based griddinevaluehas been deived byWHO, ND Nct Detected

Generally, with exception of $\mathrm{pH}$ (acidity), the physico-chemical properties of the water samples were higher in the month of March (onset of the wet season) compared to their July (peak of the rainy season) counterparts. The $\mathrm{pH}$ values ranged between 6.955 and 6.835 with a mean value of 6.890 in the month of March while its value ranged between 5.760 and 5.285 with a mean of 5.588 in the month of July. Thus, while rainwater samples from the core and intermediate were least acidic in the months of March and July respectively, rainwater samples from the urban fringe and core were most acidic in the month of March and July respectively. The $\mathrm{pH}$ values fall within the range reported in Wanzau metropolitan area in 2014 and 2015 (Zhang \& al., 2018). Rainwater sample from the core was most saline $(0.043 \mathrm{~g} / \mathrm{l})$ and least saline $(0.032 \mathrm{~g} / \mathrm{l})$ at the intermediate with a mean value of $0.036 \mathrm{~g} / \mathrm{l}$ in the month of March. Contrarily, rainwater sample from the urban fringe was most saline $(0.034 \mathrm{~g} / \mathrm{l})$ at the urban fringe while that of the core was least saline $(0.024 \mathrm{~g} / \mathrm{l})$ with a mean value of $0.030 \mathrm{~g} / \mathrm{l}$ in the month of July. The values indicate that rainwater is more saline during the onset of the wet season. Rainwater colour (Pt.Co) was highest at the intermediate (11.800) and lowest at urban fringe (6.750) with a mean value 8.850 in the month of March. Similarly, turbidity (nephelometric turbidity units) was highest at the intermediate (10.600) and lowest at the urban fringe (5.850) with a mean value of 7.800 in the month of March. Colour and turbidity were not detected in the month of July. The values of TSS (total suspended solid) were clearly higher in all the locations in the month of March. The highest 
TSS was recorded at the core $(13.750 \mathrm{mg} / \mathrm{l})$ while the lowest was recorded at the urban fringe $(10.150 \mathrm{mg} / \mathrm{l})$ with a mean value of $11.500 \mathrm{mg} / \mathrm{l}$ in the month of March. The urban fringe and intermediate had the highest $(2.900 \mathrm{mg} / \mathrm{l})$ and lowest $(1.550 \mathrm{mg} / \mathrm{l}) \mathrm{TSS}$ respectively with a mean value $2.167 \mathrm{mg} / \mathrm{l}$ in the month of July. TD S were highest $(47.750 \mathrm{mg} / \mathrm{l})$ and lowest $(35.150 \mathrm{mg} / \mathrm{l})$ at the core and intermediate respectively with a mean value of $39.650 \mathrm{mg} / \mathrm{l}$ in the month of March while its values were highest $(34.000 \mathrm{mg} / \mathrm{l})$ and least $(23.800 \mathrm{mg} / \mathrm{l})$ at the urban fringe and core respectively with a mean value of $28.300 \mathrm{mg} / \mathrm{l}$ in the month of July. The relatively drier surfaces in the month of March may have accounted for the higher values for colour, TSS and TDS in the month compared to their counterparts in the month of July.

$\mathrm{NO}_{3}$ and $\mathrm{SO}_{4}^{2 \cdot}$ were highest at the core with recorded values of $4.140 \mathrm{mg} / \mathrm{l}$ and $0.870 \mathrm{mg} / \mathrm{l}$ respectively and least at the intermediate urban fringe $(2.670 \mathrm{mg} / \mathrm{l})$ and intermediate $(0.630 \mathrm{mg} /$ l) respectively in the month of March. The values of $\mathrm{NH}_{4} \cdot \mathrm{H}$ were highest with equal concentration values of $0.155 \mathrm{mg} / \mathrm{l}$ in the month of March. $\mathrm{NH}_{4} \cdot \mathrm{H}$ was not detected in the month of July. $\mathrm{NO}_{3}, \mathrm{NH}_{4} \mathrm{H}^{2}$ and $\mathrm{SO}_{4}{ }^{2} \cdot$ in precipitation are mainly from anthropogenic sources (Zhang $\& \mathrm{al}, 1999$; Cheng \& al., 2011; Xiao \& al., 2013; Zhao \& al, 2013; Hoinaski \& al, 2014; Zhang \& al, 2018). However, while atmospheric pollution abatement strategies are being put in place in developed countries (Pénard-Morand and Annexi-Maesano, 2004; Fang \& al., 2013), Nigeria is still grappling with environment-unfriendly developments, especially in energy consumption. Thus, the rate of anthropogenic-induced atmospheric pollution, especially in urbanized landscapes will continue with adverse effects on rainwater quality. The higher values of $\mathrm{NO}_{3}$ and $\mathrm{SO}_{4}{ }^{2}$ at the core in the month of March affirm the influence of temperature on gaseous pollutants (Jayamurugan \& al., 2013). D eclining temperature gradient has been reported from the city centre to the urban fringe earlier (O djugo and Iweka, 2006). The highest values of $\mathrm{NO}_{3}$, and $\mathrm{SO}_{4}{ }^{2 \cdot}$ were recorded at the urban fringe at $0.265 \mathrm{mg} / \mathrm{l}$ and $0.175 \mathrm{mg} / \mathrm{l}$ respectively while the lowest values were recorded at the core at $0.206 \mathrm{mg} / \mathrm{l}$ and $0.130 \mathrm{mg} / \mathrm{l}$ respectively in the month of July.

O ut of the heavy metals analyzed from the rainwater samples, $\mathrm{Fe}$ had the highest concentration with a mean of $1.027 \mathrm{mg} / \mathrm{l}$ with the core having the highest $(1.275 \mathrm{mg} / \mathrm{l})$ while the intermediate had the lowest $(0.800 \mathrm{mg} / \mathrm{l})$ in the month of March. The highest concentration of $\mathrm{Fe}$ was recorded at the urban fringe $(0.295 \mathrm{mg} / \mathrm{l})$ while the least was recorded at the core $(0.235 \mathrm{mg} /$ l) with a mean value of $0.258 \mathrm{mg} / \mathrm{l}$ in the month of July. Mn concentration in the rainwater samples was highest $(0.048 \mathrm{mg} / \mathrm{l})$ and lowest $(0.029 \mathrm{mg} / \mathrm{l})$ at the core and urban fringe respectively with mean value of $0.037 \mathrm{mg} / \mathrm{l}$ in the month of March while it was highest $(0.026 \mathrm{mg} / \mathrm{l})$ at the intermediate and equally lowest $(0.020 \mathrm{mg} / \mathrm{l})$ at the core and urban fringe in the month of July with a mean value of $0.022 \mathrm{mg} / \mathrm{l}$. Maximum $(0.440 \mathrm{mg} / \mathrm{l})$ and minimum $(0.290 \mathrm{mg} / \mathrm{l})$ concentrations of $\mathrm{Zn}$ were detected at the core and urban fringe respectively with a mean value of $0.305 \mathrm{mg} / \mathrm{l}$ in the month of March while maximum $(0.126 \mathrm{mg} / \mathrm{l})$ and minimum $(0.079 \mathrm{mg} / \mathrm{l})$ were recorded at the core and intermediate respectively with a mean of $0.107 \mathrm{mg} / \mathrm{l}$ in the month of July. The concentration of $\mathrm{Cu}$ appeared to be low at all the locations irrespective of seasons. Maximum $(0.022 \mathrm{mg} / \mathrm{l})$ and minimum $(0.013 \mathrm{mg} / \mathrm{l}) \mathrm{Cu}$ were recorded at the urban fringe and intermediate respectively with a mean value of $0.017 \mathrm{mg} / \mathrm{l}$ in the month of March. Maximum $(0.007 \mathrm{mg} / \mathrm{l}) \mathrm{Cu}$ were equally recorded at the intermediate and urban fringe while minimum $(0.006 \mathrm{mg} / \mathrm{l})$ was detected at the core with a mean value of $0.007 \mathrm{mg} / \mathrm{l}$. $\mathrm{Cr}, \mathrm{Cd}$ and $\mathrm{Pb}$ were not detected in the rainwater samples from all the sampling units in the month of July. The highest $(0.009 \mathrm{mg} / \mathrm{l})$ and 
lowest $(0.006 \mathrm{mg} / \mathrm{l})$ concentrations of $\mathrm{Cr}$ were detected at the core and urban fringe respectively with the mean of $0.008 \mathrm{mg} / \mathrm{l}$ in the month of March. Cd concentrations were highest $(0.006 \mathrm{mg} / \mathrm{l})$ and lowest $(0.003 \mathrm{mg} / \mathrm{l})$ at the core and urban fringe with a mean value of $0.005 \mathrm{mg} /$ $l$ in the month of March while the highest $(0.039 \mathrm{mg} / \mathrm{l})$ and lowest $(0.008 \mathrm{mg} / \mathrm{l})$ concentrations of $\mathrm{Pb}$ were detected at the core and urban fringe with a mean value of $0.020 \mathrm{mg} /$ $l$ in the month of March. Balogun and O rimoogunje (2015) have reported correlation between land use and air pollution in Benin City. The spatial variation of the physico-chemical properties of the rainwater samples could therefore be attributed to the disparity in land use. With the exceptions of colour, turbidity, P and Fe in the month of (March) and $\mathrm{P}$ and Fe in the month of July, where WHO guidelines for drinking water are applicable, the physico-chemical properties of the rainwater samples were within permissible limits.

The statistical analysis of the difference in the physico-chemical properties of rainwater between March and July for the core, intermediate and urban fringe is presented in Table 4. The difference in the physico-chemical properties of rainwater at the core, intermediate and urban fringe showed statistical significance between March and July with t-statistics of 3.029, 3.737 and 2.764 respectively $(\mathrm{P}<0.05)$. This clearly shows that rainwater quality can vary temporarily in an urbanized area owing to meteorologicalinduced variations in the loading of atmospheric pollutants.

Table 4: T-statistics of the variation of physico-chemical properties of rainwater between March and July, 2016 Pairs Paired Differences

\begin{tabular}{|c|c|c|c|c|c|c|c|c|}
\hline & \multirow[b]{2}{*}{ Mean } & \multirow{2}{*}{$\begin{array}{c}\text { Std. } \\
\text { D eviation }\end{array}$} & \multirow{2}{*}{$\begin{array}{l}\text { Std. Error } \\
\text { Mean }\end{array}$} & \multicolumn{2}{|c|}{$\begin{array}{l}\text { 95\% Confidenœ } \\
\text { Interval of the } \\
\text { Differenœ }\end{array}$} & \multirow[b]{2}{*}{$\mathrm{t}$} & \multirow[b]{2}{*}{$\mathrm{df}$} & \multirow{2}{*}{$\begin{array}{c}\text { Sig. } \\
\text { (2-tailed) }\end{array}$} \\
\hline & & & & Lower & Upper & & & \\
\hline Core1- Core2 & 5.934 & 9.794 & 1.959 & 1.891 & 9.977 & 3.029 & 24 & .006 \\
\hline Interm ediate1- Interm ediate2 & 3.431 & 4.591 & .9183 & 1.536 & 5.327 & 3.737 & 24 & .001 \\
\hline Urban fringe1- Urban fringe2 & 2.326 & 4.209 & .842 & .589 & 4.064 & 2.764 & 24 & .011 \\
\hline
\end{tabular}

Where 1 and 2 represent dry seson and wet reson respetividy

The statistical variations of the physico-chemical properties of rainwater among the core, intermediate and urban fringe in the months of March and July are presented in Tables 5. From the analysis, rainwater appeared not to show significant spatial variation from the core to the urban fringe in Benin City during the months of March and July. As Christopherson and Byrne (2006) noted, asymmetrical geometric profiles in a city affect radiation patterns and winds. The lack of clear variation of the physico-chemical properties of rainwater from the core to the suburban could be attributed to the mixed land uses and their associated irregular shape which influence the concentration of atmospheric particulates Benin City.
Table 5: AN OVA of rainwaterquality among the core, intermediate and urban fringe

\begin{tabular}{lrrrrrr}
\hline \multicolumn{7}{c}{ March (onset of the wet season) } \\
\hline SarredVaniation & SS & Df & MS & F & P-value & F rit \\
\hline Between Groups & 319.21 & 2 & 159.60 & 0.123 & 0.88 & 3.12 \\
Within Groups & 93749.74 & 72 & 1302.08 & & & \\
Total & 94068.95 & 74 \\
\hline \multicolumn{7}{c}{ July (peak of the wet season) } \\
\hline SarcefVanation & SS & Df & MS & F & P-value & F ait \\
\hline Between Groups & 141.68 & 2 & 70.84 & 0.23 & 0.10 & 3.12 \\
Within Groups & 22467.58 & 72 & 312.05 & & & \\
Total & 22609.25 & 74 & & & & \\
\hline
\end{tabular}

The parameters with their assigned weight and relative weight based on WHO guidelines (2011) are presented in Table 6 while the computed rainwater quality index for the different sampling points are presented in Table 7. 
Table 6: Parameters with their assigned weight and relative weight of water parameters

\begin{tabular}{lllcc}
\hline $\mathrm{S} / \mathrm{N}$ & Parameter & $\begin{array}{l}\text { WHO } \\
\text { guideline(2011) }\end{array}$ & Weight(wi) & $\begin{array}{l}\text { Relative } \\
\text { weight (Wi) }\end{array}$ \\
\hline 1 & $\mathrm{pH}$ & $6.5-8.5$ & 4 & 0.077 \\
2 & $\mathrm{TDS}$ & $500 \mathrm{mg} / \mathrm{L}$ & 5 & 0.096 \\
3 & $\mathrm{EC} \mu \mathrm{S} / \mathrm{cm}$ & $500 \mathrm{mg} / \mathrm{L}$ & 4 & 0.077 \\
4 & $\mathrm{Ca}^{2+}$ & $75 \mathrm{mg} / \mathrm{L}$ & 2 & 0.038 \\
5 & $\mathrm{Mg}^{2+}$ & $30 \mathrm{mg} / \mathrm{L}$ & 2 & 0.038 \\
6 & $\mathrm{Na}^{+}$ & $200 \mathrm{mg} / \mathrm{L}$ & 4 & 0.077 \\
7 & $\mathrm{~K}^{+}$ & $200 \mathrm{mg} / \mathrm{L}$ & 2 & 0.038 \\
8 & $\mathrm{Cl}^{-}$ & $250 \mathrm{mg} / \mathrm{L}$ & 3 & 0.058 \\
9 & $\mathrm{NO}_{3}$ & $45 \mathrm{~m} / \mathrm{L}$ & 5 & 0.096 \\
10 & $\mathrm{SO}_{4}{ }^{-2}$ & $250 \mathrm{mg} / \mathrm{L}$ & 4 & 0.077 \\
11 & $\mathrm{HCO}{ }_{3}$ & $500 \mathrm{mg} / \mathrm{L}$ & 1 & 0.019 \\
12 & $\mathrm{Fe}$ & $0.3 \mathrm{~m} / \mathrm{L}$ & 4 & 0.077 \\
13 & $\mathrm{Mn}$ & $0.1 \mathrm{~m} / \mathrm{L}$ & 3 & 0.058 \\
14 & $\mathrm{Zn}$ & $3.0 \mathrm{~m} / \mathrm{L}$ & 2 & 0.038 \\
15 & $\mathrm{~Pb}$ & $0.01 \mathrm{~m} / \mathrm{L}$ & 4 & 0.077 \\
16 & $(\mathrm{NH} 4-\mathrm{N})$ & $0.5 \mathrm{~m} / \mathrm{L}$ & 3 & 0.058 \\
\hline & & & $\sum \mathrm{wi}=52$ & $\sum \mathrm{Wi}=1.00$ \\
& & & &
\end{tabular}

Table 7: Computed WQ I for the sampling points

\begin{tabular}{lllll}
\hline Site & $\begin{array}{l}\text { Water Quality } \\
\text { Index March }\end{array}$ & $\begin{array}{l}\text { Water quality } \\
\text { interpretation }\end{array}$ & $\begin{array}{l}\text { Water } \\
\text { Quality } \\
\text { Index July }\end{array}$ & $\begin{array}{l}\text { Water quality } \\
\text { interpretation }\end{array}$ \\
\hline Core & 80.91 & Good & 15.10 & Poor \\
Intermediate & 46.04 & Excellent & 15.51 & Excellent \\
Urban fringe & 46.39 & Excellent & 17.40 & Excellent \\
\hline
\end{tabular}

The computed sub-index of parameters and the overall WQI for March and July are presented in Appendices 1 and 2. While TDS and $\mathrm{NO}_{3}{ }^{-}$had the highest relative weight (0.096), $\mathrm{HCO}_{3}$ had the lowest relative weight (0.019). Rainwater quality was excellent at the core, intermediate and urban fringe in the month of July while it was excellent at the intermediate and urban fringe and good at the core in the month of March. The excellent quality of rainwater buttresses its recommendation for drinking and other domestic uses (Issaka $\notin \mathrm{al}, 2015)$, especially in the month of March. It is important to note that water quality index values are better in the month of July. This shows that the atmosphere is cleaner in the month of July which is one of the peaks of the rainy season in the rainforest belt of Nigeria where
Benin City is located. Besides, the month of March marks the onset of the wet season in the rainforest belt of Nigeria (O dekunle, 2004; Atedhor and John-Abebe, 2017). Rainfall plays a vital role in the removal of pollutants from the atmosphere. However, the distinction in WQI at the Core between the March and July confirms that the efficiency and rate of washout scavenging are only partly a function of rainfall rate (Oke, 2002). Thus, although rainwater is relatively free from impurities (Mohammed $\mathbb{a}$ al, 2018), this depends on season and location. Furthermore, the direction of transportation of atmospheric pollutants is influenced by wind profile and direction. A tmospheric stagnation can also influence the concentration of atmospheric concentration of pollutants.

Air pollutants concentrations in urban areas have been blamed on anthropogenic sources such as road traffic and industries in France, China, Brazil, Malaysia, e.t.c. (Xiao \& al., 2013; Pénard-Morand and Annexi-Maesano, 2004; Hoinaski \& al., 2014; Zhang et al., 2018). Rainwater quality is influenced by air pollutants (Hoinaski \&al, 2014). The higher concentration of the physico-chemical properties of rainwater in the core of Benin City, especially during the onset of the wet season could be attributed to higher vehicular traffic. As revealed in Figure 1, the major streets in Benin City converge at the core which is a central business district (CBD). The CBD coupled with administrative functions attract high vehicular influx to the core of the city. A part from the type and intensity of emission, the concentration of air pollutants is also influenced by meteorological parameters and topography (O ke, 2002; PénardMorand and Annexi-Maesano, 2004; Jayamurugan \&al., 2013; Zhang \& al, 2018). Rainwater quality is expected to vary with environmental circumstances (Despins et al., 2009). Meteorological parameters such as rainfall and humidity, temperature, wind speed and direction 
vary on a seasonal basis. Meteorological conditions affect dilution and diffusion of pollutants in the atmosphere ( $\mathrm{Zu}$ \& al., 2018). These seasonal meteorological changes may have largely accounted for the variation of the physicochemical properties of rainwater at the different locations between the months of March and July.

\section{Conclusion}

The paper examined the spatial and temporal variations of the physico-chemical properties of rainwater at the core, intermediate and urban fringe of Benin City between the months of March and July (2016). With the exceptions of colour, turbidity, P, Fe in the month of March and $\mathrm{P}$ and $\mathrm{Fe}$ in the month of July, physicochemical properties of rainwater from all the locations, where WHO guidelines for drinking water are applicable, were within permissible limits. Spatially, rainwater showed insignificant variations in March and July. Temporarily, rainwater differed significantly at the core, intermediate and urban fringe between the months of March and July. The WQI values were excellent at the core, intermediate and urban fringe in the month of July while its values were excellent at the intermediate and urban fringe and good at the core in the month of March. The better WQI values in the month of July indicate that the efficiency and rate of washout scavenging of atmospheric pollutants increase with rainfall amount considering the fact that the month of July coincides with one of the rainfall peaks in the rainforest belt where Benin City is located. The distinction in rainwater quality between the core and the intermediate and urban fringe in the month of March suggests that besides the role of rainfall in atmospheric cleansing, other factors such as wind profile and direction and atmospheric stagnation also play critical control on the concentration of atmospheric pollutants and by extension rainwater quality.

\section{References}

Abua, M.A., Afangideh, A.I., O chiche, A. and Ashua, S.W. (2014) Assessment of quality status of

Calabar River around Tinapa-A diabo catchment, Cross river State, Nigeria. Port Harcourt Jaumal of Social Säenes 5 (1 \& 2): 224-234

Artaxo, P., Martins, J.V., Yamosoe, M., Proscopio, A.S., Pauliquevis, T.M., Andreae, M.O., Guyon, P., Gatti, L.V. and Leav, A.M.C. (2002) Physical and chemical properties of aerosols in the wet and dry seasons in Rondônia, Amazonia. Jaumal of Geophysical Research, Vol. 107 (D 20), 8081. doi:10.1029/ 2001JD 000666

Atedhor G.O. and John-Abebe, R.O. (2017) Towards warmer onsets of the rainy and dry seasons in the

forest belt of Nigeria. Jarmal of Meteordoy and Related Sciences, 10, 2-12. https:// doi.org/ $\underline{10.20987 / \text { jmrs.1.01.2017 }}$

Ayeni, A.O. and Soneye, A.S.O. (2014) $\mathrm{G}$ roundwater quality assessment for domestic uses in the micro-

geomorphological units of Lagos, Nigeria. Futy Jaumal of the Enviranment, 8 (1): 93-106

Ayeni, A.O. and Atedhor, G.O. (2017) Surface water quality in selected farming settlements of southwestern Nigeria. Journal of Nigerian Enirormental Socidy, 11, 108-123

Babalola, O.S. and Akinsanola, A.A. (2016) Change detection in land surface temperature and land use land cover over Lagos metropolis, Nigeria. Jaumal of RemteSensing\& G.I.S, 5: 171. doi:10.4172/ 2469-4134.10001 71

Baklanov, A., Grimmond, C.S.B., Carlson, D., Terblanche, D., Tang, X., Bouchet, V., Lee, 
B., Langendijk, G., Kolli, R.K. and Hovsepyan, A. (2017) From urban meteorology, climate and environment research to integrated city services. Unban Climate, http:/ / dx.doi.org/ 10.1016/ j.uclim.2017.05.004

Balogun, I. and Adegun, B. (2011) Leachate contamination of potential and its impact on the hydrochemistry of Olusosun, Abule-Egba and Solous 1 dumpsites in Lagos. NigerianGeogaphical Jaumal, 7 (2): 28-42

Balogun, I. and Adegun, B. (2012) Variability of ground water quality around selected dumpsites in Lagos metropolis. Ife Reseanch Pudication in Geogaphy, 11 (1): 42-51

Balogun, I. and Balogun, A. (2014) Urban heat island and bioclimatological conditions in a hothumid tropical city: the example of Akure. DIE ERDE, 145 (1-2): 3-15

Balogun, V.S. and Orimoogunje, O.O.I. (2015) The correlation between land use activities and air pollution in a part of southern Nigeria. Nigeian Geographical Jaumal, 10 (2): 92-109

Balogun, I.I, Sojobi, A.O., and Oyedepo, B.O. (2016) Assessment of rainfall variability, rainwater

harvesting potential and storage requirements in O deta Local G overnment Area of O gun State in South-western Nigeria. CogettEnvironment Saiene, 2: 1138597, http:// dx.doi.org/ 10.1080/ 23311843.2016.1138597

Cheng, Y., Liu, Y., Huo, M., Sun, Q., Wang, H., Chen, Z. and Bai, Y. (2011) Chemical characteristics of

precipitation at Nanping Mangdang Mountain in eastern China during spring. Journal of
Eniranmental Saience, 23 (8): 1350-1358. D O I: 10.1016/ S1001-0742(10)60560-8

Christopherson, R.W. and Byrne, M. (2006) Geosystems: An Introduction to physical Geography

(Canadian Edition). Prentice Hall, Toronto

Despins, C., Farahbakhsh, K. and Leidl, C. (2009) Assessment of rainwater quality from rainwater harvesting systems in O ntario, Canada. Jourmal of Water Supply: Research and Tednnology-AQUA, 58.2: 117-134. doi: 10.2166/ aqua.2009.013

Fang, Y., Wang, X., Zhu, F., Wu, Z., Li, J., Zhong, L., Chen, D. and Yoh, M. (2013) Three-decade changes in chemical composition of precipitation in Guangzhou city, southern China: has precipitation recovered from acidification following sulphur dioxide emission control? Telus B: Cherical and Physical Meteordogy, 65:1, 20213, D O I: 10.3402/ tellusb.v65i0.20213

George, K., Ziska, L.H., Bunce, J.A. and Q uebedeaux, B. (2007) Elevated atmospheric CO 2

concentration and temperature across an urbanrural transect. A tmospheic Envirarment, 41, 76547665

Hoinaski, L., Franco, D., Haab, R., Martins, R.F. and Lisboa, H.M. (2014) Investigation of rainwater

contamination sources in the southern part of Brazil. Enironmental Tehndoy, 35 (7): 868-881. h t tp:// dx.doi.org/ 10.1080/ 09593330.2013 .854412

Idso, S.B., Idso, C. D. and Balling, R.C. Jr (2002) Seasonal and diurnal variations of near-surface atmospheric $\mathrm{CO} 2$ concentration within a residential sector of the urban $\mathrm{CO}_{2}$ dome of 
Phoenix, AZ, USA. Atmospheic Enmironment, 36: 1655-1660

Inkani, A.I. (2016) Domestic expenditure as determinant of vulnerability to water scarcity of rural

households in Katsina State. Nigerian Geogaphical Jaumal, 11 (1): 201-213

Issaka, R. Z., Ibrahim, H., Issah, M.H. (2015) Effect of seasonal variation on quality of domestic water

sources in Central G onja D istrict. TheIntemational Jaumal of Engineeing and Saience, 4 (9): 1-8

Jayamurugan, R., Kumaravel, B., Palanivelraja, S. and Chockalingam, M.P. (2013) Influence of temperature, relative humidity and seasonal variability on ambient air quality in a coastal urban area. International Jaumal of Atmospheic Saienes Volume 2013, Article ID 264046, http:/ / dx.doi.org/ 10.1155/ 2013/ 264046

McG rane, S.J. (2016) Impacts of urbanisation on hydrological and water quality dynamics, and urban

water management: a review. Hydrdogical Sảences Joumal, 61, 13, 2295-2311

h t tp:/ / dx.doi.org/ $10.1080 /$ 02626667.2015.1128084

Mohammed, I.U., Abdullahi, A.M. and Muhammed, M.M. (2018) Rainwater harvesting for human

consumption - A review of the public health implications and perspectives. Nigerian Resernch Jarmal of Engineering and Environmental Sciences, 3(1): 217-228

Mohammed, I.U., Ndadi, A.K. Ahmed, S.D., Hayatu, J.M. and Nwude, M.O. (2018) Rainwater harvesting for water supply and integrated development in rural and semi-urban areas. Nigerian Research Journal of Engineering and Enviranmental Saienes 3(1): 287-304

O dekunle, T.O. (2004) Rainfall and length of the growing season in Nigeria. Intemational Jarmal of Climatdogy, 24, 467-479

O djugo, P.A.O. and Iweka, D.A. (2006) The impact of urbanization on microclimates: A case study of

Benin City, Nigeria. Jauml of eniromental Saence 10 (1): $68-80$

O ke, T.R. (2002) Bandarylayerdimates Taylor and Francis E-Libary

Papafotiou, E. and Katsifarakis, K.L. (2015) Ecological rainwater management in urban areas: preliminary considerations for the city of Corinth, G reece. Agiailtureand Agiailtural SienceProcedia, 4, 383-391

Pénard-Morand, C. and Annexi-Maesano, I. (2004) Air pollution: from sources of emissions to health

effects. Breathe, 2 (1): 109-119

Ramakrishnaiah, C. R., Sadashivaiah, C. and Ranganna, G. (2009): Assessment of Water Quality Index

for the G roundwater in TumkurTaluk, Karnataka State, India, E-Jaumal of Chemistry, 6 (2), 523-530. http:// www.e-journals.net

Sahu, P. andSikdar, P. K. (2008) Hydrochemical framework of the aquifer in and around East Kolkata

Wetlands, West Bengal. India Environ Ged, 55 (4): 823-835.10.1007/ s00254-007-1034-x 
Vasanthavigar, M., Srinivasamoorthy, K., Vijayaragavan, K., Rajiv Ganthi, R., Chidambaram, S.,

Anandhan, P., Manivannan, R. and Vasudevan, S. (2010) Application of water quality index for groundwater quality assessment: Thirumanimuttar sub-basin, Tamilnadu, India, Enviromental Monitaing and Assessment, 171 (14): 595-609

WHO (2011) Guidelines for drinking-water Quality, Fouth edition, $564 \mathrm{pp}$.

Xiao, H., Xiao, H., Long, A., Wang, Y. and Liu, C. (2013) Chemical composition and source apportionment of rainwater at Guiyang, SW China. Journal of Atmospheic Chemistry, 70: 269281. D OI 10.1007/ s10874-013-9268-3

Xu, Y., Xue, W., Lei, Y., Zhao, Y., Cheng, S., Ren, Z. and Huang, Q. (2018) Impact of meteorological conditions on PM2.5 pollution in China during Winter. Atmosphere 9, 429. doi:10.3390/ atmos9110429

Yusuf, Y.O. and Oladipo, E.O. (2012) An assessment of the problems and prospects of domestic water supply in Zaria City, Kaduna State. Ife Resench Publication in Geogaphy, 11 (1): 126-134

Zhang, J., Chen, S. Z., Yu, Z. G., Wang, C. S. and Wu, Q. M. (1999) Factors influencing changes in rainwater composition from urban versus remote regions of the Yellow Sea. Jamal of Geephysical Research 104 (D 1): 1631-1644
Zhang, L., Qiao, B., Wang, H., Tian, M., Cui, J., Fu, C., Huang, Y. and Yan F. (2018) Chemical characteristics of precipitation in a typical urban site of the hinterland in three Gorges reservoir, China. Jaumal of Chemistry, Volume 2018, Article ID 2914313, https:/ / doi.org/ 10.1155/ 2018/ 2914313

Zhao, M., Li, L., Liu, Z., Chen, B., Huang, J., Cai, J., Deng, H. (2013) Chemical composition and sources

of rainwater collected at a semi-rural site in Ya'an, southwestern China. A tmospheric and Climate Saienes 3: 486-496. http:/ / dx.doi.org/ 10.4236/ acs.2013.34051

Zhong, S., Qian, Y., Zhao, C, Leung, R., Wang, H., Yang, B., Fan, F., Yan, H., Yang, X., and Liu, L.

(2017) Urbanization-induced urban heat island and aerosol effects on climate extremes in the Yangtze River D elta region of China. AtmosphericChenistry and Physics 17: 5439-5457, doi:10.5194/ acp-175439-2017 


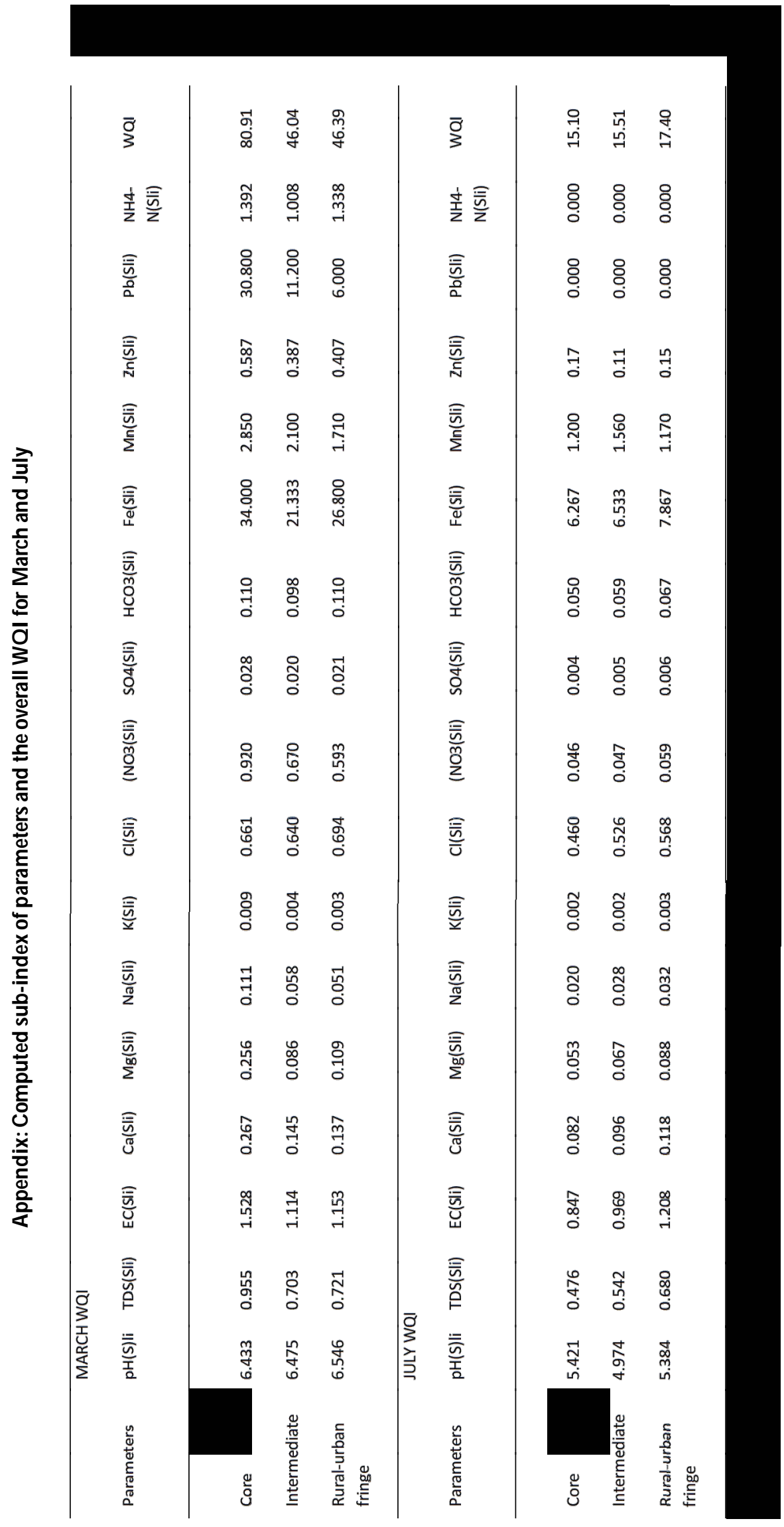

